\title{
KADAR Na+, K+, Cl-, DAN KALSIUM TOTAL SERUM DARAH SERTA HUBUNGANNYA DENGAN TEKANAN DARAH PADA PENDERITA HIPERTENSI
}

\section{PUSPITA ANGGRAINI, RUSDI \& ERMITA IBRAHIM ILYAS}

Jurusan Biologi FMIPA Universitas Negeri Jakarta (UNJ). Jl. Pemuda No. 10 Rawamangun, Jakarta Timur. 13220. Indonesia.

Email: fiianggreini@gmail.com

Tanngal publikasi online:

\begin{abstract}
Hypertension is currently still a major problem in the world. In Indonesia, the number of hypertension tends to increase every year. One of the causes of hypertension is high salt consumption. This research was held to identify levels of $\mathrm{Na}+, \mathrm{K}+, \mathrm{Cl}$ - and total calcium in blood serum and to analyze the relationship among levels of $\mathrm{Na}+, \mathrm{K}+, \mathrm{Cl}$ - and total calcium with blood pressure. This study was conducted on March to May 2014 using a Crosssectional method. The result showed that $\mathrm{Na}+$ level in hypertensive patient significantly higher compared in normotensive $(p=0.000) . K+$ level in hypertensive patient significantly lower than normotensive $(\mathrm{p}=0.002)$. In addition, no significant between $\mathrm{Cl}$ - level $(\mathrm{p}=0.514)$ and total calcium level $(\mathrm{p}=0.417)$ in hypertensive patients and normotensive subject. There was a significant relationship between $\mathrm{Na}+$ level with systolic blood pressure ( $\mathrm{rs}=0.419)$ and diastolic blood pressure $(\mathrm{rs}=0.455)$. There was a significant relationship between $\mathrm{K}+$ level with systolic blood pressure ( $\mathrm{rs}=-0.403)$ and diastolic $(\mathrm{rs}=-0.496)$. There was no significant relationship between $\mathrm{Cl}$ - level with systolic blood pressure $(\mathrm{rs}=0.071)$ and diastolic $(\mathrm{rs}=0.092)$. There was significant relationship between total calcium level with systolic blood pressure ( $\mathrm{rs}=-0.393)$ and no significant with diastolic ( $\mathrm{rs}=-0.306)$. In conclusion, there were significant differences in the level of $\mathrm{Na}+$ and $\mathrm{K}+$ in hypertensive patient and normotensive and a significant relationship among level of $\mathrm{Na}+$ and $\mathrm{K}+$ with blood pressure. There were no significant differences in the levels of $\mathrm{Cl}$ - and total calcium in hypertensive patient and normotensive and no significant relationship among levels of $\mathrm{Cl}$ - and total calcium with blood pressure.
\end{abstract}

Key Words: blood pressure, $\mathrm{Cl}$-, hypertension, $\mathrm{K}+, \mathrm{Na}+$, total calcium

\section{PENDAHULUAN}

Hipertensi adalah meningkatnya tekanan darah di atas normal. Hipertensi sering disebut sebagai the silent disease karena umumnya penderita tidak mengetahui dirinya menderita hipertensi sebelum memeriksakan tekanan darahnya. Hipertensi merupakan faktor risiko utama terjadinya penyakit jantung, stroke, gangguan penglihatan dan penyakit ginjal (Bustan, 2007). Hipertensi 
saat ini masih menjadi masalah utama di dunia. Menurut Joint National Committee on Prevention, Detection, Evaluation, and Treatment on High Blood Pressure VII (JNC-VII) Amerika Serikat, hampir 1 milyar orang menderita hipertensi di dunia (Chobanian et al., 2003) dan diperkirakan akan meningkat hingga $60 \%$ pada tahun 2025 dengan total 1,56 miliar orang menderita tekanan darah tinggi (Kearney et al., 2005).

Di Indonesia masalah hipertensi cenderung meningkat. Hasil survei Riskesdas (Riset Kesehatan Dasar) pada tahun 2013, terjadi peningkatan penderita hipertensi dari 7,6 persen pada tahun 2007 menjadi 9,5 persen tahun 2013 (Riskesdas, 2013). Hipertensi terjadi akibat faktor lingkungan, faktor genetik, dan interaksi antara keduanya. Faktor lingkungan yang paling berdampak pada tekanan darah adalah faktor makanan atau pola makan, dimana faktor inilah yang paling berperan dalam homeostasis tekanan darah (Lawrence et al., 2005). Penderita hipertensi secara umum cenderung meningkat diduga disebabkan oleh perubahan gaya hidup secara global yang berperan besar. Mudahnya mendapatkan makanan siap saji membuat konsumsi sayuran segar dan serat berkurang namun konsumsi garam, lemak, gula, dan kalori meningkat.

Hasil analisis Riset Kesehatan Dasar (Riskesdas) 2013, seperti dikutip dari Balitbang Depkes, menunjukkan pada tahun 2010 sebanyak 26,2\% penduduk Indonesia berusia di atas 10 tahun mengonsumsi makanan asin setiap hari. Selain itu, konsumsi lemak penduduk indonesia setiap harinya mencapai 40,7\% (Riskesdas, 2013). Terlebih lagi perubahan ini disertai penurunan aktivitas fisik (Palmer et al., 2007). Pada penderita hipertensi esensial, reabsorpsi natrium pada tubulus ginjal meningkat karena stimulasi beberapa natrium pengangkut yang terletak di membran luminal serta pompa natrium yang terletak di membran basolateral (Meneton, 2005). Peningkatan reabsorpsi ion natrium $(\mathrm{Na}+)$ berakibat pula pada peningkatan sekresi ion kalium $(\mathrm{K}+)$ di tubulus distal dan kolektivus ginjal (Krum, 2007). Otak akan merespon terhadap konsumsi garam yang tinggi dengan merangsang kelenjar adrenal untuk menyekresikan sebuah faktor endogen yaitu Endogenous digitalis-like factor (EDLF) (Blaustein et al., 2006). Pelepasan EDLF akan menyebabkan retensi natrium dengan meningkatkan aktivitas dan ekspresi pompa natrium pada ginjal (Ferrari, 2006). Retensi natrium melalui pelepasan EDLF dan keadaan hipokalemia akan menghambat pompa ( $\mathrm{Na}+/ \mathrm{K}+$ - ATPase) pada arteri dan arteriolar sel otot polos pembuluh darah, sehingga meningkatkan konsentrasi natrium dan mengurangi konsentrasi kalium dalam cairan intraseluler (Blaustein et al., 2006).

Peningkatan natrium intraseluler akan merangsang penukar natrium-kalsium $(\mathrm{Na}+/ \mathrm{Ca} 2+)$ pada membran sel otot polos untuk membawa kalsium ke dalam sel, hal ini menyebabkan kalsium sitosol meningkat yang dapat memicu kontraksi otot polos pembuluh darah (vasokontriksi) dan menyebabkan tekanan darah menjadi tinggi (Ferrari et al., 2006). Pada sel otot jantung, peningkatan $\mathrm{Ca} 2+$ pada sitosol sel otot ini akan menyebabkan $\mathrm{Ca} 2+$ mengikat suatu protein kontraktil yaitu troponin, sehingga troponin akan terlepas dari ikatannya dengan aktin-miosin dan memungkinkan interaksi aktin-miosin bekerja memicu kontraksi. Hal ini akan memperkuat dan meningkatkan kontraksi otot jantung sehingga terjadi peningkatan tekanan darah. Meningkatnya tekanan darah persisten pada penderita hipertensi esensial masih belum banyak dipelajari serta masih sedikitnya penelitian yang menghubungkan antara kadar elektrolit yaitu natrium, kalium, dan klorida serta 
kalsium total dengan kejadian hipertensi, maka perlu dilakukan penelitian untuk mengetahui kadar $\mathrm{Na}+, \mathrm{K}+, \mathrm{Cl}-$ dan kalsium total pada serum darah penderita hipertensi.

\section{METODE PENELITIAN}

Pengambilan sampel darah penderita hipertensi dan pengukuran kadar $\mathrm{Na}+, \mathrm{K}+$, dan $\mathrm{Cl}-$ dilakukan di Rumah Sakit Umum Daerah (RSUD) Kabupaten Bekasi, sedangkan pengukuran kadar kalsium total dilakukan di laboratorium Prodia, Jalan Kramat Raya Salemba, Jakarta. Penelitian dilaksanakan pada bulan Maret- Mei 2014.

Metode penelitian yang digunakan dalam penelitian ini adalah metode Cross- Sectional. Pada penelitian ini, peneliti mengumpulkan data tekanan darah pasien hipertensi kemudian ditelusuri variabel yang diduga berperan terhadap peningkatan tekanan darah yaitu $\mathrm{Na}+, \mathrm{K}+, \mathrm{Cl}-$, dan Kalsium total. Sampel yang digunakan dalam penelitian ini adalah serum darah dari 25 pasien penderita hipertensi esensial di Poliklinik Penyakit Dalam RSUD Kabupaten Bekasi dan 25 orang normotensi. Alat yang digunakan dalam penelitian terdiri dari Stetoskop, Sphygmomanometer, Terumo 3mL, Mikrotube, Mikropipet $(100 \mu \mathrm{l}-1000 \mu \mathrm{l})$, Mikrotips, Sentrifuge, Kotak Pendingin, Kuvet, seperangkat alat Electrolyte 5+ Analyzer, Cup Sample ukuran 1500 $\mu \mathrm{L}$, Needle Holder, Vacutainer, Spuit merk Alkohol Swab, Plester, Tabung Plain tutup merah 3mL, kamera, alat tulis dan buku catatan. Sedangkan bahan-bahan yang digunakan adalah darah $3 \mathrm{~mL}$, Test Reagen Elektrolit dan es batu.

\section{HASIL PENELITIAN}

\section{Deskripsi Data}

Serum darah yang didapatkan digunakan untuk memeriksa kadar $\mathrm{Na}+, \mathrm{K}+, \mathrm{Cl}-$, dan kalsium total. Pemeriksaan kadar $\mathrm{Na}+, \mathrm{K}+$, dan Cl- dilakukan di Laboratorium RSUD Kabupaten Bekasi, sedangkan pemeriksaan kalsium total dilakukan di Laboratorium Prodia Jalan Kramat raya, Jakarta Pusat. Selanjutnya dilakukan pengolahan data mengenai kadar $\mathrm{Na}+, \mathrm{K}+, \mathrm{Cl}-$, dan kalsium total pada subjek penderita hipertensi dan normotensi serta analisis hubungan antara variabel tersebut

Tabel 1. Karakteristik subjek penelitian

\begin{tabular}{lll}
\hline Keterangan & Hipertensi & Normotensi \\
\hline Banyak Subjek & 25 & 25 \\
Rata-rata usia, Tahun & $47.0 \pm 6.4$ & $42.5 \pm 7.9$ \\
Jenis Kelamin, L/P & 18 -Jul & 15 -Oct \\
Indeks Masa Tubuh (IMT), Kg/m2 & $23.9 \pm 3.4$ & $23.5 \pm 2.9$ \\
Tekanan Darah Sistolik, mm Hg & $160.8 \pm 20.85$ & $118 \pm 8.2$ \\
Tekanan Darah Diastolik, mm Hg & $98.4 \pm 11.8$ & $76.4 \pm 5.7$ \\
\hline
\end{tabular}

dengan tekanan darah subjek hipertensi menggunakan program SPSS versi 16.0.

Dari Tabel 1 di atas, ditunjukkan bahwa rata-rata usia subjek penelitian penderita hipertensi adalah 47.0 \pm 6.4 tahun dan rata-rata usia subjek normotensi adalah $42.5 \pm 7.9$ tahun. Usia minimum 
Tabel 2. Rata-rata kadar $\mathrm{Na}+, \mathrm{K}+, \mathrm{Cl}-$, dan kalsium total

\begin{tabular}{lll}
\hline Keterangan & Hipertensi & Normotensi \\
\hline $\mathrm{Na}+$ Serum, mmol/L & $146.6 \pm 1.8$ & $144.3 \pm 2.7$ \\
$\mathrm{~K}+$ Serum, mmol/L & $3.9 \pm 0.5$ & $4.4 \pm 0.5$ \\
$\mathrm{Cl}-$ Serum, mmol/L & $8.7 \pm 0.5$ & $8.8 \pm 0.3$ \\
Kalsium Total Serum, mg/dL & $109.1 \pm 2.0$ & $108.2 \pm 2.5$ \\
\hline
\end{tabular}

pada subjek hipertensi adalah 35 tahun dan usia maksimum adalah 55 tahun, sedangkan usia minimum pada subjek normotensi adalah 30 tahun dan usia maksimum adalah 55 tahun. Rata-rata indeks masa tubuh (IMT) pada subjek penderita hipertensi adalah $23.9 \pm 3.4 \mathrm{Kg} / \mathrm{m} 2$ dan pada subjek normotensi, ratarata indeks masa tubuhnya adalah $23.5 \pm 2.9 \mathrm{Kg} / \mathrm{m} 2$. Rata-rata tekanan darah sistol pada subjek penderita hipertensi adalah $160.8 \pm 20.8 \mathrm{mmHg}$ dan rata-rata tekanan darah diastolnya adalah $98.4 \pm 11.8 \mathrm{mmHg}$. Sedangkan pada subjek normotensi ratarata tekanan darah sistoliknya adalah $118 \pm 8.2 \mathrm{mmHg}$ dan rata-rata tekanan darah diastoliknya adalah $76.4 \pm 5.7 \mathrm{mmHg}$. Dari Tabel 2 diatas, ditunjukkan ratarata kadar $\mathrm{Na}+$ pada serum darah penderita hipertensi adalah $146.6 \pm 1.8$

Tabel 3. Hasil wawancara dengan subjek penelitian

\begin{tabular}{ll}
\hline Informasi & Keterangan \\
\hline Usia didiagnosa menderita hipertensi & 30 tahun, 33 tahun, 34 tahun, 35 tahun, 37 tahun, 38 \\
& tahun, 39 tahun, 40 tahun, 41 tahun, 43 tahun, 44 tahun, \\
& 45 tahun, 50 tahun \\
Gejala menderita hipertensi & Pusing, mual, kembung, penglihatan gelap dan kabur \\
Keturunan & $72 \%$ penderita menyatakan ada riwayat keluarga dengan \\
& penyakit yang sama \\
Suka makanan asin & $76 \%$ penderita menyatakan menyukai makanan asin \\
\hline
\end{tabular}

mmol/L, sedangkan rata-rata kadar $\mathrm{Na}+$ pada serum darah subjek normotensi adalah $144.3 \pm 2.7$ $\mathrm{mmol} / \mathrm{L}$.

Rata-rata kadar $\mathrm{K}+$ pada serum darah penderita hipertensi adalah $3.9 \pm 0.5 \mathrm{mmol} / \mathrm{L}$ dan ratarata kadar $\mathrm{K}+$ pada serum darah subjek normotensi adalah $4.4 \pm 0.5$. Rata-rata kadar Cl- pada serum darah penderita hipertensi adalah $109.1 \pm 2.0 \mathrm{mmol} / \mathrm{L}$ dan rata-rata kadar Cl- pada serum darah subjek normotensi adalah 108.2 $\pm 2.5 \mathrm{mmol} / \mathrm{L}$. Rata-rata kadar kalsium total pada serum darah penderita hipertensi adalah $8.7 \pm 0.5 \mathrm{mg} / \mathrm{dL}$ dan rata-rata kadar kalsium total pada serum darah

Tabel 4. Gambaran Tekanan Darah pada Penderita Hipertensi

\begin{tabular}{lll}
\hline Kategori Hipertensi (JNC VII) & Jumlah Penderita & Persentase (\%) \\
\hline Hipertensi Derajat I & 11 orang & $44 \%$ \\
Hipertensi Derajat II & 14 orang & $56 \%$ \\
\hline
\end{tabular}

subjek normotensi adalah $8.8 \pm 0.3 \mathrm{mg} / \mathrm{dL}$. Data sekunder pada penelitian ini didapatkan melalui wawancara dengan subjek penelitian penderita hipertensi. Tabulasi data hasil wawancara kemudian dibuat dirangkum pada Tabel 3. 
Hasil data wawancara yang telah dirangkum kemudian dianalisis secara deskriptif. Tabel 3 menunjukkan informasi yang berkaitan dengan penderita Hipertensi. Dapat dilihat bahwa usia subjek penelitian penderita Hipertensi ketika di diagnosa menderta hipertensi adalah 30 tahun, 33 tahun, 34 tahun, 35 tahun, 37 tahun, 38 tahun, 39 tahun, 40 tahun, 41 tahun, 43 tahun, 44 tahun, 45 tahun, 50 tahun. Gejala yang timbul pada penderita Hipertensi antara lain pusing, mual, kembung, penglihatan gelap dan kabur. 72\% penderita menyatakan memiliki riwayat hipertensi. Sebesar 76\% penderita menyatakan menyukai makanan asin.

Dari Tabel 4, ditunjukkan sebanyak 11 orang penderita hipertensi (44\% dari total sampel

Tabel 5. Hasil uji beda rata menggunakan Uji t (untuk kadar K+)

\begin{tabular}{llll}
\hline \multirow{2}{*}{ Variabel } & \multicolumn{2}{l}{ Nilai Rata-rata } & $\mathrm{P}$ \\
\cline { 2 - 4 } & Hipertensi & Normotensi & \\
\hline $\mathrm{K}+$ Serum & 3.98 & 4.452 & 0.002 \\
\hline
\end{tabular}

penderita) menderita hipertensi derajat I yaitu memiiki tekanan darah sistolik antara 140-159 mmHg atau tekanan darah diastoliknya antara 90-99 mmHg. Sedangkan, sebanyak 14 orang (56\%) menderita hipertensi derajat II yaitu memiliki tekanan darah sistolik $\geq 160 \mathrm{mmHg}$ atau tekanan darah diastoliknya $\geq 100 \mathrm{mHg}$.

Uji perbedaan antara kadar $\mathrm{Na}+, \mathrm{K}+, \mathrm{Cl}$-, dan kalsium total rata-rata pada penderita hipertensi dan normotensi

Hasil perbandingan nilai rata-rata kadar Kalium pada serum darah antara penderita hipertensi dengan subjek normotensi menggunakan uji t dengan software SPSS versi 16.0 ditunjukkan pada Tabel 5. Pada Tabel 6, ditunjukkan nilai ratarata kadar $\mathrm{K}+$ pada serum darah penderita hipertensi lebih rendah dari pada nilai ratarata subjek normotensi $(3.980<4.452)$ dengan nilai signifikansi

Tabel 6. Hasil uji beda rata menggunakan Uji U Mann-Whitney (untuk kadar Na+, Cl-, dan kalsium total)

\begin{tabular}{llll}
\hline \multirow{2}{*}{ Variabel } & \multicolumn{2}{l}{ Nilai Rata-rata } & $\mathrm{P}$ \\
\cline { 2 - 4 } & Hipertensi & Normotensi & \\
\hline Kalsium total serum & 146.6 & 144.3 & 0 \\
Cl- Serum & 109.2 & 108.2 & 0.514 \\
Na+ Serum & 8.7 & 8.8 & 0.417 \\
\hline
\end{tabular}

0.002. Karena nilai signifikansi $\mathrm{p}<0.05$ maka dapat disimpulkan bahwa terdapat perbedaan rata-rata yang signifikan antara kadar $\mathrm{K}+$ pada serum darah penderita hipertensi dengan normotensi. Hasil perbandingan nilai rata-rata kadar $\mathrm{Na}+, \mathrm{Cl}$ - dan kalsium total pada serum darah antara penderita hipertensi dengan subjek normotensi menggunakan uji U Mann-Whitney dengan software SPSS versi 16.0 ditunjukkan pada Tabel 6 .

Dari Tabel 6, ditunjukkan nilai ratarata kadar $\mathrm{Na}+$ pada serum darah penderita hipertensi lebih besar dari pada nilai ratarata subjek normotensi $(146.6>144.3)$ dengan nilai $p=0.000$. Karena nilai $\mathrm{p}<0.05$ maka dapat disimpulkan bahwa terdapat perbedaan rata-rata yang signifikan antara kadar $\mathrm{Na}+$ pada serum darah penderita hipertensi dengan normotensi. Nilai rata-rata kadar Cl- pada serum 
darah penderita hipertensi lebih besar dari pada nilai rata-rata subjek normotensi (109.1>108.2) dengan nilai $p=0.514$. Karena nilai $p>0.05$ maka dapat disimpulkan bahwa tidak terdapat perbedaan rata-rata antara kadar Cl- pada serum darah penderita hipertensi dengan normotensi. Nilai rata-rata kadar kalsium total pada serum darah penderita hipertensi lebih rendah dari pada nilai rata-rata subjek normotensi $(8.7<8.8)$ dengan nilai $p=0.417$. Karena nilai $p>0.05$ maka dapat disimpulkan bahwa tidak terdapat perbedaan rata-rata antara kadar kalsium total pada serum darah penderita hipertensi dengan normotensi.

Uji Korelasi antara Kadar $\mathrm{Na}+, \mathrm{K}+, \mathrm{Cl}$-, dan Kalsium Total Serum Darah dengan Tekanan Darah

Tabel 7. Hasil uji korelasi antara kadar $\mathrm{Na}+, \mathrm{K}+, \mathrm{Cl}-$ dan Kalsium total serum darah dengan tekanan darah sistolik pada penderita hipertensi menggunakan uji Spearman's Correlation

\begin{tabular}{lll}
\hline \multicolumn{3}{c}{ TEKANAN DARAH SISTOLIK } \\
\hline Variabel & Koef. Korelasi (rs) & Sig. (p) \\
\hline $\mathrm{Na}+$ serum & 0.419 & 0.018 \\
$\mathrm{~K}+$ serum & -0.403 & 0.023 \\
$\mathrm{Cl}-$ serum & 0.071 & 0.368 \\
Kalsium total serum & -0.393 & 0.026 \\
\hline
\end{tabular}

\section{pada Penderita Hipertensi}

Uji korelasi antara kadar $\mathrm{Na}+, \mathrm{K}+, \mathrm{Cl}$ - dan kalsium total pada serum darah dengan tekanan darah pada subjek penelitian penderita hipertensi menggunakan Spearman's Correlation test. Adapun kriteria yang digunakan dalam penelitian ini adalah interpretasi koefisien korelasi menurut Sarwono, 2006. Hasil korelasi tersebut dapat dilihat pada Tabel 7.

Pada Tabel 7, ditunjukkan bahwa korelasi antara tekanan darah sistolik dengan kadar $\mathrm{Na}+$ memiliki nilai rs=0.419 yang dapat dikategorikan memiliki kekuatan korelasi yang cukup dan positif (berbanding lurus) artinya jika kadar $\mathrm{Na}+$ pada serum darah tinggi maka tekanan darah sistolik juga akan meningkat. Berdasarkan uji signifikasi hasilnya menunjukkan nilai $\mathrm{p}=0.018<0.05$ maka H0 ditolak, artinya terdapat hubungan signifikan antara tekanan darah sistolik dengan kadar $\mathrm{Na}+$ pada

Tabel 8. Hasil uji korelasi antara kadar $\mathrm{Na}+, \mathrm{K}+, \mathrm{Cl}-$ dan Kalsium total serum darah dengan tekanan darah diastolik pada penderita hipertensi menggunakan uji Spearman's Correlation.

\begin{tabular}{lll}
\hline & \multicolumn{2}{c}{ TEKANAN DARAH SISTOLIK } \\
\hline Variabel & Koef. Korelasi (rs) & Sig. (p) \\
\hline $\mathrm{Na}+$ serum & 0.455 & 0.011 \\
$\mathrm{~K}+$ serum & -0.496 & 0.006 \\
$\mathrm{Cl}-$ serum & 0.092 & 0.331 \\
Kalsium total serum & -0.306 & 0.068 \\
\hline
\end{tabular}

serum darah. Untuk korelasi antara tekanan darah sistolik dengan kadar $\mathrm{K}+$ memiliki nilai rs $=-$ 0.403 yang dapat dikategorikan memiliki kekuatan korelasi yang cukup dan negatif (berbanding terbalik) artinya jika kadar $\mathrm{K}+$ pada serum darah tinggi maka tekanan darah sistolik akan menurun. 
Berdasarkan uji signifikansi hasilnya menunjukkan nilai $\mathrm{p}=0.023<0.05$ maka $\mathrm{H} 0$ ditolak, artinya terdapat hubungan signifikan antara tekanan darah sistolik dengan kadar $\mathrm{K}+$ pada serum darah.

Korelasi antara tekanan darah sistolik dengan kadar $\mathrm{Cl}$ - memiliki nilai $\mathrm{rs}=0.071$ yang dapat dikategorikan memiliki kekuatan korelasi yang sangat lemah dan positif (berbanding lurus) artinya jika kadar Cl- pada serum darah tinggi maka tekanan darah sistolik akan meningkat. Berdasarkan uji signifikansi hasilnya menunjukkan nilai $\mathrm{p}=0.368>0.05$ maka H0 diterima, artinya tidak terdapat hubungan signifikan antara tekanan darah sistolik dengan kadar Cl- pada serum darah. Untuk hasil korelasi antara tekanan darah sistolik dengan kadar kalsium total memiliki nilai rs $=-0.393$ yang dapat dikategorikan memiliki kekuatan korelasi yang sangat lemah dan negatif (berbanding terbalik) artinya jika kadar kalsium total pada serum darah tinggi maka tekanan darah sistolik akan menurun. Berdasarkan uji signifikansi hasilnya menunjukkan nilai $\mathrm{p}=0.026<0.05$ maka H0 ditolak, artinya terdapat hubungan signifikan antara tekanan darah sistolik dengan kadar kalsium total pada serum darah.

Pada Tabel 8, ditunjukkan bahwa korelasi antara tekanan darah diastolik dengan kadar $\mathrm{Na}+$ memiliki nilai rs $=0.455$ yang dapat dikategorikan memiliki kekuatan korelasi yang cukup dan positif (berbanding lurus) artinya jika kadar $\mathrm{Na}+$ pada serum darah tinggi maka tekanan darah diastolik juga akan meningkat. Berdasarkan uji signifikasi hasilnya menunjukkan nilai $p=0.011<0.05$ maka H0 ditolak artinya terdapat hubungan signifikan antara tekanan darah sistolik dengan kadar $\mathrm{Na}+$ pada serum darah. Korelasi antara tekanan darah diastolik dengan kadar $\mathrm{K}+$ memiliki nilai $\mathrm{rs}=-0.496$ yang dapat dikategorikan memiliki kekuatan korelasi yang cukup dan negatif (berbanding terbalik) artinya jika kadar $\mathrm{K}+$ pada serum darah tinggi maka tekanan darah diastolik akan menurun.

Berdasarkan uji signifikansi hasilnya menunjukkan nilai $\mathrm{p}=0.006<0.05$ maka H0 ditolak, artinya terdapat hubungan signifikan antara tekanan darah diastolik dengan kadar $\mathrm{K}+$ pada serum darah. Korelasi antara tekanan darah diastolik dengan kadar $\mathrm{Cl}$ - memiliki nilai rs=0.092 yang dapat dikategorikan memiliki kekuatan korelasi yang sangat lemah dan positif (berbanding lurus) artinya jika kadar Cl- pada serum darah tinggi maka tekanan darah diastolik juga akan meningkat. Berdasarkan uji signifikansi hasilnya menunjukkan nilai $\mathrm{p}=0.331>0.05$ maka $\mathrm{H} 0$ diterima, artinya tidak terdapat hubungan signifikan antara tekanan darah diastolik dengan kadar Cl- pada serum darah.

Hasil korelasi antara tekanan darah diastolik dengan kadar kalsium total memiliki nilai rs=-0.306 yang dapat dikategorikan memiliki kekuatan korelasi cukup dan negatif (berbanding terbalik) artinya jika kadar kalsium total pada serum darah tinggi maka tekanan darah diastolik akan menurun. Berdasarkan uji signifikansi hasilnya menunjukkan nilai $\mathrm{p}=0.068>0.05$ maka $\mathrm{H} 0$ diterima, artinya tidak terdapat hubungan signifikan antara tekanan darah diastolik dengan kadar kalsium total pada serum darah.

\section{PEMBAHASAN}

Perbandingan kadar $\mathrm{Na}+, \mathrm{K}+, \mathrm{Cl}$-, dan kalsium total pada penderita hipertensi dan normotensi

$\mathrm{Kadar} \mathrm{Na}+, \mathrm{K}+, \mathrm{Cl}-$, dan kalsium total diperoleh dari $3 \mathrm{~mL}$ sampel darah yang dikumpulkan 
dari 25 orang penderita hipertensi dan 25 orang normotensi. Berdasarkan Tabel 6, terlihat bahwa terdapat perbedaan yang signifikan antara kadar $\mathrm{Na}+$ serum pada penderita hipertensi dengan subjek normotensi dimana rata-rata kadar $\mathrm{Na}+$ serum pada hipertensi $(146.6 \pm 1.8 \mathrm{mmol} / \mathrm{L})$ lebih tinggi dibandingkan dengan normotensi $(144.3 \pm 2.7 \mathrm{mmol} / \mathrm{L})$. Hasil penelitian ini sesuai dengan penelitian Barbagallo et al. (2000) yang menyebutkan bahwa kadar $\mathrm{Na}+$ serum pada penderita hipertensi lebih tinggi dibandingkan normotensi (141.0 $\pm 0.4>140.8 \pm 0.4 \mathrm{mmol} / \mathrm{L})$. Menurut Kee (1996) dan Chris (2010), kadar Natrium dalam darah normalnya adalah 135-145 mmol/L, dan pada penelitian ini hasil rata-rata kadar $\mathrm{Na}+$ pada serum melampaui batas normal kadar $\mathrm{Na}+$ dalam darah yang ditetapkan.

Hugh (2004) menjelaskan bahwa terdapat kasus dengan kadar natrium serum lebih besar dari $147 \mathrm{mmol} / \mathrm{L}$ pada 27\% penderita hipertensi tanpa dipengaruhi usia. Hal ini dimungkinkan karena sebagian besar penderita hipertensi yang menjadi subjek penelitian ini (sebanyak $76 \%$ penderita) menyatakan suka mengonsumsi makanan asin (Tabel 3). Penelitian sebelumnya menjelaskan bahwa tekanan darah meningkat ketika asupan natrium tinggi. Asupan tinggi natrium diperkirakan menyebabkan 17\% dari kasus hipertensi (Silzer, 2007). Pada pengobatan hipertensi, asupan natrium yang dianjurkan adalah 70-100 meq natrium setiap harinya, dapat dicapai dengan tidak memberi garam pada makanan selama atau sesudah memasak dan menghindari makanan yang diawetkan dengan kandungan natrium besar (Benowitz, 2002).

Pembatasan ini dilakukan karena peranan potensial natrium dalam menimbulkan tekanan darah tinggi (Almatsier, 2002). Natrium memiliki hubungan yang sebanding dengan timbulnya hipertensi. Semakin banyak jumlah natrium di dalam tubuh, maka akan terjadi peningkatan volume plasma, curah jantung dan tekanan darah. Meskipun demikian, respon seseorang terhadap jumlah natrium di dalam tubuh berbeda-beda (Irza, 2009).

Konsumsi natrium yang berlebih menyebabkan konsentrasi natrium didalam cairan ekstraselular meningkat. Ketika konsentrasi natrium didalam cairan ekstraseluler meningkat maka tekanan osmotik darah akan meningkat pula, hal ini menyebabkan osmoreseptor pada hipotalamus akan terangsang kemudian kelenjar hipofisis akan dirangsang lebih aktif untuk menyekresikan hormon ADH yang bersifat antidiuretik untuk meningkatkan permeabilitas tubulus ginjal terhadap air sehingga reabsorpsi air pada tubulus distal dan duktus koligentes ginjal meningkat. Akibatnya, volume cairan ekstraselular meningkat dan menyebabkan meningkatnya volume darah. Jantung harus memompa keras untuk mendorong volume darah yang meningkat melalui ruang pembuluh darah sehingga tekanan darah menjadi tinggi (hipertensi) (Sobel et al., 1999). Hasil wawancara pada penelitian ini menyebutkan bahwa $72 \%$ penderita hipertensi memiliki riwayat keluarga dengan penyakit yang sama, sehingga selain faktor asupan natrium yang tinggi dapat diketahui bahwa $72 \%$ subjek penderita hipertensi memiliki kelainan genetik yang diwariskan dari orang tua yang memiliki riwayat hipertensi (Oparil et al., 2003).

Menurut Tanaka (1997), dalam penelitiannya menjelaskan bahwa pada penderita hipertensi yang disertai riwayat penyakit dari orang tua memiliki kepekaan natrium yang tinggi. Kepekaan natrium didefinisikan sebagai peningkatan tekanan darah dalam menanggapi asupan natrium klorida yang lebih tinggi dari batas yang dianjurkan untuk di konsumsi. Pada penelitian ini, terlihat 
bahwa terdapat perbedaan yang signifikan antara kadar $\mathrm{K}+$ serum pada penderita hipertensi dengan subjek normotensi dimana rata-rata kadar $\mathrm{K}+$ serum pada hipertensi $(3.9 \pm 0.5 \mathrm{mmol} / \mathrm{L})$ lebih rendah dibandingkan dengan normotensi $(4.4 \pm 0.5 \mathrm{mmol} / \mathrm{L})$.

Hasil penelitian ini didukung dengan penelitian Barbagallo et al. (2000) yang menyebutkan bahwa kadar $\mathrm{K}+$ serum pada penderita hipertensi lebih rendah dibandingkan normotensi $(4.1 \pm 0.06<4.5 \pm 0.07 \mathrm{mmol} / \mathrm{L})$. Menurut Sacher (2002), nilai rujukan kadar Kalium dalam darah normalnya adalah 3.5-5.3 mmol/L, dan pada penelitian ini hasil rata-rata kadar $\mathrm{K}+$ baik pada serum penderita hipertensi maupun subjek normotensi masih terdapat diambang batas normal nilai rujukan. Namun, rata-rata kadar $\mathrm{K}+$ pada serum darah penderita hipertensi hampir mendekati ambang batas minimum nilai rujukan. Hal ini terjadi karena kehilangan kalium akibat redistribusi kalium ekstraselular ke dalam cairan intraselular. Keadaan ini dapat menyebabkan keletihan, kelemahan otot, kram kaki, kelemahan otot, mual, muntah, dan penurunan konsentrasi urin (Horne, 2000).

Kadar kalium harus dikontrol ketat dalam batas yang aman karena gradien $\mathrm{K}+$ di kedua sisi membran sel sangat menentukan potensial listrik membran tersebut dimana potensial listrik ini memengaruhi eksitabilitas listrik pada jaringan seperti saraf dan otot, termasukjantung (Chris, 2010). Oleh karena itu, apabila subjek penderita hipertensi pada penelitian ini tidak ditangani dengan segera melalui terapi ataupun asupan kalium yang cukup, maka akan menyebabkan keadaan hipokalemia (kadar kalium dibawah normal). Cara kerja kalium berlawanan dengan natrium. Konsumsi kalium yang banyak akan meningkatkan konsentrasinya di dalam cairan intraselular, sehingga cenderung menarik cairan dari bagian ekstraselular dan menurunkan tekanan darah (Hendrayani, 2009). Pada hasil wawancara (Tabel 3), sebagian besar penderita hipertensi suka mengonsumsi makanan asin, hal ini mengakibatkan meningkatnya absorpsi ion natrium $(\mathrm{Na}+)$ dan sekresi ion kalium $(\mathrm{K}+)$ pada tubulus distal dan kolektivus (Krum, 2007). Jika peningkatan sekresi $\mathrm{K}+$ pada ginjal terjadi terus-menerus, maka akan mengakibatkan berkurangnya kadar kalium dalam darah. Hal ini sesuai dengan hasil penelitian ini yang menyebutkan bahwa kadar kalium pada serum darah penderita hipertensi lebih rendah dibandingkan normotensi (Tabel 5).

Peningkatan asupan kalium dapat menghilangkan kepekaan natrium pada penderita hipertensi (Lawrence, 2005). Hal ini didukung dengan pernyataan Horacio (2007) yang menyatakan peningkatan asupan kalium dapat menyelamatkan lebih dari setengah juta nyawa selama dekade berikutnya. Namun, asupan kalium tidak boleh melebihi kadar yang dianjurkan seperti konsumsi suplemen kalium secara terus menerus, karena akan menyebabkan irama jantung yang tidak teratur dan jantung berdebar cepat (Johnson, 2008). Pada penelitian ini, terlihat bahwa tidak terdapat perbedaan yang signifikan antara kadar Cl- serum pada penderita hipertensi dengan subjek normotensi dimana rata-rata kadar Cl- serum pada hipertensi (109.1 $\pm 2.0 \mathrm{mmol} / \mathrm{L})$ lebih tinggi dibandingkan dengan normotensi $(108.2 \pm 2.5 \mathrm{mmol} / \mathrm{L})$ namun tidak berbeda jauh. Hal ini dikarenakan $\mathrm{Cl}$ - merupakan ion yang dapat melewati membran dengan transport pasif, sehingga ketika dalam sel tubulus ginjal kadar Cl- meningkat, maka akan dikeluarkan ke lumen tubulus secara transport pasif melewati membran luminal.

Hasil ini juga didukung dengan hasil wawancara yang menyebutkan $76 \%$ penderita hipertensi menyukai konsumsi makanan asin, yaitu makanan yang mengandung unsur natrium dan klorida. 
Sehingga, ketika konsumsi garam meningkat, maka kadar natrium dan klorida juga akan meningkat, karena ion natrium $(\mathrm{Na}+)$ selalu berpasangan dengan ion klorida $(\mathrm{Cl}-)$ yang akan memberikan kontribusi lebih dari 90\% terhadap efektif osmolalitas di dalam cairan ekstraseluler (Irawan, 2007). Rekomendasi untuk menghindari makanan tinggi asupan garam untuk pencegahan dan pengobatan hipertensi sering diungkapkan dalam diet natrium.

Hasil penelitian sebelumnya menunjukkan bahwa komponen klorida pada garam adalah juga memiliki peran penting sebagai penyebab tingginya tekanan darah (Theodore, 2005). Penelitian lain menunjukkan peningkatan tekanan darah pada penderita hipertensi terjadi ketika diberi asupan natrium klorida yang tinggi, namun tidak terjadi peningkatan tekanan darah ketika asupan natrium tersebut berupa natrium sitrat, natrium bikarbonat, atau natrium fosfat. Hal ini menunjukkan bahwa kombinasi natrium dengan klorida dapat memengaruhi tekanan darah (Tanaka, 1997). Pada penderita hipertensi, pengurangan tekanan darah oleh asupan makanan yang mengandung kalium lebih efektif oleh kalium klorida dibandingkan dengan kalium sitrat (Overlack, 1995). Namun pada penelitian ini tidak didapatkan korelasi yang signifikan antara kadar Cl- pada penderita hipertensi dan normotensi, hal ini dimungkinkan karena Cl- tidak memiliki efek secara langsung terhadap terjadinya kontraksi pada sel otot polos pembuluh darah, namun Cl- memiliki pengaruh dalam meningkatkan osmolalitas cairan ekstraseluler.

Hasil penelitian ini menunjukkan bahwa terdapat perbedaan yang signifikan antara kadar kalsium total pada penderita hipertensi dengan subjek normotensi dimana rata-rata kadar kalsium total serum pada hipertensi $(8.7 \pm 0.5 \mathrm{mg} / \mathrm{dL})$ lebih rendah dibandingkan dengan normotensi $(8.8 \pm 0.3 \mathrm{mg} / \mathrm{dL})$. Hasil ini didukung dengan penelitian Sudhakar (2004) yang menyebutkan bahwa kadar kalsium total pada penderita hipertensi lebih rendah daripada subjek normotensi $(2.23 \pm 0.36<2.52 \pm 0.24 \mathrm{mmol} / \mathrm{L})$. Hal ini dikarenakan $\mathrm{Ca} 2+$ pada cairan ekstraseluler dipompa masuk ke sitosol sel otot polos akibat aktivasi penukar natrium-kalsium tipe 1 pada membran sel otot polos. Aktifnya penukar ini akibat kadar natrium dalam sitosol meningkat dan hanya dapat dikeluarkan melalui penukar tersebut, sehingga $\mathrm{Ca} 2+$ intraseluler mengalami peningkatan dan menyebabkan kontraksi otot polos pembuluh darah dan tekanan darah menjadi tinggi (Ferrari et al., 2006). Kalsium terionisasi ( $\mathrm{Ca} 2+)$ dalam tubuh bertindak sebagai second messenger intraseluler dalam mengatur eksitasi dan kontraksi di sel-sel otot polos pembuluh darah.

Konsentrasi kalsium intraseluler menentukan ketegangan sel otot polos pembuluh darah, dengan demikian kalsium berkontribusi terhadap tahanan perifer (peripheral resistance). Peningkatan tahanan perifer ditemukan dalam kasus hipertensi (Sudhakar, 2004). Dengan demikian, metabolisme kalsium yang terganggu diduga memainkan peran penting dalam patofisiologi hipertensi esensial (Yingshui, 2013).

Korelasi antara Kadar $\mathrm{Na}+, \mathrm{K}+, \mathrm{Cl}$-, dan Kalsium Total Serum Darah dengan Tekanan Darah pada Penderita Hipertensi

Tekanan darah adalah kekuatan yang dihasilkan oleh darah terhadap setiap satuan luas dinding pembuluh darah yang dinyatakan dalam milimeter air raksa (mmHg) (Guyton, 2006). Tekanan darah sangat penting dalam sistem sirkulasi darah dan selalu diperlukan untuk mendorong aliran darah dalam arteri, arteriola, kapiler dan sistem vena, sehingga terbentuklah suatu aliran darah 
yang konstan (Masud, 1996). Tekanan darah terbagi menjadi 2 jenis, yaitu tekanan sistolik dan diastolik. Tekanan sistolik adalah tekanan yang dihasilkan pada saat jantung mulai berdenyut dan berkontraksi memompa darah keluar dari jantung. Sedangkan tekanan diastolik adalah tekanan yang dihasilkan pada saat jantung berelaksasi setelah berdenyut.

Hasil penelitian ini menunjukkan ada atau tidaknya korelasi antara tekanan darah baik tekanan darah sistolik maupun tekanan darah diastolik dengan kadar $\mathrm{Na}+, \mathrm{K}+, \mathrm{Cl}$-, dan kalsium total serum darah. Pada Tabel 7 diatas memperlihatkan korelasi antara tekanan darah sistolik dengan kadar $\mathrm{Na}+, \mathrm{K}+, \mathrm{Cl}-$, dan Kalsium total serum darah variabel tersebut, sedangkan Tabel 8 memperlihatkan korelasi antara tekanan darah diastolik dengan variabel tersebut menggunakan uji Spearman's Correlation. Pada variabel kadar Na+ memiliki korelasi signifikan dan positif baik pada tekanan darah sistolik maupun diastolik, artinya jika kadar $\mathrm{Na}+$ pada serum darah tinggi maka tekanan darah baik sistolik maupun diastolik akan meningkat secara signifikan dengan kekuatan hubungan yang cukup. Hal ini didukung dengan penelitian Wannamethee et al., (1994) yang menemukan hubungan positif antara kadar natrium serum dengan tekanan darah sistolik pada subjek hipertensi, namun di penelitian ini memiliki kekuatan hubungan yang kuat.

Penelitian ini mendapatkan sebanyak $76 \%$ subjek penelitian penderita hipertensi mengakui bahwa suka mengonsumsi makanan asin (Tabel 3). Hal ini dapat dikaitkan dengan adanya korelasi antara kadar $\mathrm{Na}+$ yang berasal dari konsumsi makanan asin (mengandung garam tinggi) dengan tekanan darah sistolik dan diastolik pada penderita hipertensi. Pada Hasil ini didukung pula dengan studi sebelumnya, bahwa pada subjek penelitian yang diberi asupan garam meningkat secara bertahap terjadi peningkatan kadar natrium pada plasma, dan terdapat hubungan yang signifikan antara peningkatan kadar natrium pada plasma dengan peningkatan tekanan darah (Wardener, 2001). Pada manusia, meningkatnya tekanan darah karena efek peningkatan asupan natrium secara tiba-tiba selama 5-28 hari dikaitkan dengan faktor usia.

Pada usia muda (di bawah 26 tahun), tekanan darah sistolik maupun diastolik tidak meningkat meskipun mungkin terdapat peningkatan kadar natrium pada plasma dan volume darah (Heer, 2000). Sebaliknya, pada individu dengan usia lebih dari 60 tahun (kebanyakan telah menderita tekanan darah tinggi), peningkatan asupan natrium dapat menyebabkan tekanan darah sistolik dan diastolik semakin meningkat disertai dengan adanya peningkatan kadar natrium plasma dan volume darah (Johnson, 2001). Kadar K+ memiliki korelasi signifikan dan negatif baik pada tekanan darah sistolik maupun diastolik, artinya jika kadar $\mathrm{K}+$ pada serum darah rendah maka tekanan darah baik sistolik maupun diastolik akan meningkat secara signifikan dengan kekuatan hubungan cukup. Hasil ini didukung dengan penelitian Whelton (2003) yang menyebutkan bahwa terdapat hubungan terbalik antara asupan kalium dengan tekanan darah, prevalensi hipertensi dan risiko terjadinya stroke.

Keterbatasan asupan kalium menyebabkan kurangnya kadar kalium dalam sel, sehingga memicu sel untuk mendapatkan natrium agar tonisitas dan volume sel tetap terjaga (Androgue, 1994). Penelitian epidemiologi menunjukkan bahwa asupan rendah kalium dalam jangka waktu yang lama akan mengakibatkan renal vascular remodeling yang mengindikasikan terjadinya resistansi pembuluh darah pada ginjal. Sedangkan, konsumsi kalium dalam jumlah yang tinggi dapat 
melindungi individu dari hipertensi. Hal ini dikarenakan kalium dapat menurunkan tekanan darah sistolik dan diastolik. Namun, asupan kalium tidak boleh melebihi batas konsumsi yang dianjurkan yaitu 4700mg/hari pada usia 14 tahun keatas, karena jika konsumsi kalium dalam jumlah tinggi dan tidak sesuai anjuran, maka dapat menyebabkan keadaan hiperkalemia yaitu keadaan dimana kadar kalium dalam tubuh melebihi kadar normalnya (Lestari, 2010). Kadar ion klorida (Cl-) memiliki korelasi yang tidak signifikan baik pada tekanan darah sistolik maupun diastolik pada penderita hipertensi (Tabel 7 dan 8).

Hal ini dimungkinkan karena $\mathrm{Cl}$ - tidak memiliki efek secara langsung terhadap terjadinya kontraksi pada sel otot polos pembuluh darah, namun Cl- memiliki pengaruh dalam meningkatkan osmolalitas cairan ekstraseluler. Pada Tabel 7 menunjukkan kadar Cl- dengan tekanan darah baik dengan sistolik maupun diastolik memiliki korelasi positif dan kekuatan korelasinya sangat lemah. Hal ini dikarenakan $\mathrm{Cl}$ - dapat melakukan transport pasif, khususnya transport pada membran luminal sel tubulus ginjal sehingga $\mathrm{Cl}$ - yang berlebihan dapat langsung dikeluarkan ke tubulus ginjal melalui saluran pada membran luminal yang terbuka (Horacio et al. 2007).

Kadar kalsium total memiliki korelasi yang signifikan dan negatif dengan kekuatan hubungan yang cukup pada tekanan darah sistolik artinya jika kadar kalsium total pada serum darah rendah maka tekanan darah sistolik akan meningkat secara signifikan. Pada penelitian ini, korelasi antara kalsium total dengan tekanan darah diastolik memiliki korelasi negatif dan tidak signifikan dengan kekuatan hubungan yang cukup. Hal ini berhubungan dengan berlebihnya kadar natrium dan kurangnya kadar kalium dalam tubuh dan memicu kontraksi otot polos pada pembuluh darah dengan bantuan kalsium ion dalam sel otot polos. Peran terpenting kalsium ekstrasel dalam regulasi didukung oleh kalsium reseptor pada membran sel (Brown, 1995). Ca2+ memengaruhi tekanan darah dengan memberi efek pada total tahanan perifer melalui pengaturan protein kontraktil, membran transport retikuler, aktivitas metabolisme dalam otot polos pembuluh darah dan pengendalikan sinyal transduksi (Carl, 1996).

Pada penelitian ini, dilakukan pengukuran pada kalsium total bukan pada $\mathrm{Ca} 2+$ intraseluler yang memiliki pengaruh langsung terhadap mekanisme kontraksi otot polos pembuluh darah dikarenakan $\mathrm{Ca} 2+$ memiliki proporsi 50\% dari jumlah kalsium total, sehingga dapat diasumsikan ketika ion kalsium memiliki pengaruh terhadap kontraksi otot polos, maka kalsium total juga memliki pengaruh yang sama (Ganong, 2001). Kalsium terionisasi pada ekstrasel memiliki konsentrasi lebih tinggi daripada intrasel. Hal ini dicapai dengan adanya proses penukaran kalsium di membran sel yang bergantung pada hidrolisis adenosin trifosfat (ATP) dalam menyediakan energi untuk pompa kalsium terhadap proton. Kalsium dipompa dari ekstrasel kedalam intrasel oleh tiga pompa secara terpisah yang terletak pada membran sel yaitu: (1) pompa kalsium-magnesium-ATPase, (2) sistem penukar kalsium dan natrium (Ca- Na) dan (3) pompa kalsium-hidrogen (Ganong, 2001).

Penyebab kadar kalsium pada serum darah penderita hipertensi rendah dikarenakan adanya perubahan pada sistem neurohormonal yang terkait dengan keseimbangan cairan dan elektrolit. Dalam keadaan ini, korteks adrenal akan banyak menghasilkan aldosteron sebagai hormon yang bertanggung jawab terhadap keseimbangan cairan dan elektrolit (Gharbawy et al., 2001). Aldosteron akan meningkatkan reabsorpsi $\mathrm{Na}+$ dan air berakibat pula pada peningkatan sekresi $\mathrm{K}+$ di tubulus 
distal dan koligentes ginjal (Krum, 2007). Sekresi Kalium yang berlebihan akan mengakibatkan terjadinya hipokalemia (kekurangan Kalium dalam darah) dan memicu keadaan depolarisasi pada membran sel (Iwamoto, 2006). Depolarisasi membran dalam sel otot polos pembuluh darah akan menyebabkan terjadinya peningkatan kalsium intraseluler $(\mathrm{Ca} 2+)$ karena aktifnya tegangan ion channel kalsium di membran, ion channel kalsium di retikulum sarkoplasma, dan pompa natrium kalsium (Iwamoto, 2006).

Peningkatan konsentrasi $\mathrm{Ca} 2+$ mengaktifkan ion channel kalsium di retikulum sarkoplasma dan membran sel baik pada sel otot polos maupun sel otot jantung. Pada sel otot polos pembuluh darah, aktifnya ion channel pada sel dapat menyebabkan kadar $\mathrm{Ca} 2+$ dalam sitosol meningkat. Hal ini mengakibatkan peningkatan $\mathrm{Ca} 2+$ yang berikatan dengan kalmodulin yang telah terikat dengan suatu protein kinase yang dikenal sebagai Myosin Light Chain Kinase (MLCK), sehingga meningkatkan aktivitas enzim ini. Peningkatan aktivitas enzim tersebut akan merangsang interaksi antara aktin dan miosin, meningkatkan siklus cross-bridge, maka kekuatan kontraksi meningkat pula. Kontraksi otot polos pada dinding pembuluh darah menyebabkan penyempitan diameter pembuluh darah dan menyebabkan tekanan darah tinggi (Newsholme et al., 2010).

Faktor yang berperan dalam mencetus keadaan hipertensi khususnya hipertensi primer bukan saja karena asupan garam yang berlebih sehingga dapat mengakibatkan ketidakseimbangan elektrolit dalam tubuh, melainkan banyak faktor lainnya seperti genetik, usia, jenis kelamin, obesitas, serta faktor lingkungan seperti merokok, konsumsi makanan yang diawetkan dan mengandung lemak, alkohol, stres dan kurangnya aktivitas fisik/olahraga. Kejadian hipertensi pada pria sama dengan wanita. Namun pada penelitian ini didapatkan hasil bahwa $72 \%$ subjek penderita hipertensi adalah wanita (Tabel 3). Hal ini kemungkinan disebabkan karena pola makan wanita yang suka makanan ringan yang mengandung bahan pengawet dan garam, serta kurangnya aktivitas fisik pada wanita dibanding lakilaki. Selain itu wanita cenderung lebih peduli terhadap kesehatannya, sehingga sering memeriksakan kesehatannya ke rumah sakit. Pada penelitian Pemu et al. (2008) subjek yang menderita hipertensi lebih banyak pada wanita disebabkan stenosis (penyempitan) pada arteri ginjal hingga fibromuscular dysplasia yang sering terjadi pada wanita dibandingkan lakilaki sedangkan pada hipertensi sekunder lebih banyak diderita wanita dikarenakan penggunaan alat kontrasepsi oral, preeklamsia, dan peradangan pada pembuluh darah (vasculitides). Hipertensi meningkat seiring dengan pertambahan usia (Kumar et al., 2005).

Pada hasil wawancara penelitian ini, usia pertama kali subjek penelitian didiagnosa menderita hipertensi adalah pada usia $\geq 30$ tahun sebanyak $20 \%, \geq 40$ tahun sebanyak $32 \%$ dan usia $\geq 50$ tahun $48 \%$. Meningkatnyajumlah subjek penderita hipertensi disertai peningkatan usia dikarenakan adanya perubahan fisiologis, terutama terjadi peningkatan resistensi perifer dan aktivitas saraf simpatik. Selain itu, kurangnya sensitivitas baroreseptor dan peran ginjal yang mulai menurun sehingga aliran darah ginjal dan laju filtrasi glomerulus menurun pada akhirnya menyebabkan hipertensi (Kumar et al., 2003). Ditambah lagi dengan konsumsi garam yang tinggi, dapat menyebabkan meningkatnya kadar $\mathrm{Na}+$ pada plasma darah dan terjadi kontraksi pada pembuluh darah (vasokontriksi), sehingga tahanan perifer meningkat dan mengakibatkan tekanan darah meningkat pula. Sebagian besar penderita hipertensi mengaku merasakan gejala menderita hipertensi yaitu pusing (sakit kepala), 
mual, dan penglihatan kabur. Mekanisme fisiologis yang terlibat dalam sebab-akibat sakit kepala pada di penderita hipertensi tetap tidak jelas dan kontroversial.

Penelitian sebelumnya melaporkan pada hipertensi yang tidak terkendali dapat meningkatkan frekuensi dan beratnya serangan migrain, atau bahkan mengubah bentuk migrain episodik (kadangkadang) menjadi sakit kepala harian yang kronis (Yeung, 2006) Sakit kepala pada hipertensi dikarenakan adanya peningkatan tekanan intrakranial dan terkadang merupakan efek samping dari beberapa obat antihipertensi contohnya obat golongan nitrat dan statin (Friedman, 2002).

Sakit kepala dan rasa mual pada penderita hipertensi disebabkan karena terjadinya vasokontriksi sehingga menyebabkan berkurangnya suplai oksigen ke otak. Pada penderita hipertensi, jantung bekerja lebih keras untuk mengedarkan darah yang mengandung oksigen ke seluruh tubuh. Namun jika keadaan ini terjadi dalam jangka waktu yang lama, dan jantung tidak dapat mengimbanginya sehingga anggota tubuh termasuk otak mulai kekurangan suplai oksigen, hal ini menyebabkan penderita merasa mual, sakit kepala dan tekanan pada karotid meningkat. Jika aliran darah berkurang pada bagian otot jantung, maka dapat menyebabkan rasa nyeri di dada dan berakibat gangguan pada masalah otot jantung. Bahkan, dapat menyebabkan timbulnya serangan jantung. Pada penderita hipertensi yang mengonsumsi obat anti hipertensi, maka akan terjadi vasodilatasi sehingga suplai oksigen akan kembali meningkat ke seluruh organ tubuh dan mengakibatkan tekanan intrakranial meningkat.

Hal ini menyebabkan penderita hipertensi yang mengonsumsi obat anti hipertensi akan mendapatkan efek samping berupa sakit kepala dan rasa mual. Penderita hipertensi (tekanan darah tinggi) dianjurkan untuk secara rutin melakukan pengukuran tekanan darah dan mengurangi asupan makan yang mengandung kadar garam tinggi serta mengonsumsi makanan dengan kandungan kalium dan kalsium yang tinggi seperti buah, sayuran dan susu. Sehingga tekanan darah dapat di kontrol agar tidak meningkat secara persisten yang disebabkan oleh kadar elektrolit yang tidak seimbang dalam tubuh.

\section{KESIMPULAN}

1. Kadar Natrium $(\mathrm{Na}+)$ pada serum darah penderita hipertensi lebih tinggi dibanding dengan normotensi, secara bermakna. 2. Kadar Kalium $(\mathrm{K}+)$ pada serum darah penderita hipertensi lebih rendah dibanding normotensi, secara bermakna. 3. Kadar Klorida (Cl-) pada serum darah penderita hipertensi lebih tinggi dibanding normotensi, namun tidak bermakna. 4. Kadar kalsium total pada serum darah penderita hipertensi lebih rendah dibanding normotensi, namun tidak bermakna. 5 . Terdapat hubungan berbanding lurus antara kadar $\mathrm{Na}+$ pada serum darah dengan tekanan darah sistolik dan diastolik pada penderita hipertensi, secara bermakna. 6. Terdapat hubungan berbanding terbalik antara kadar ion $\mathrm{K}+$ pada serum darah dengan tekanan darah sistolik dan diastolik pada penderita hipertensi, secara bermakna. 7. Terdapat hubungan berbanding lurus antara kadar Clpada serum darah dengan tekanan darah sistolik dan diastolik pada penderita hipertensi, namun tidak bermakna. 8. Terdapat hubungan berbanding terbalik antara kadar kalsium total pada serum darah dengan tekanan darah sistolik, secara bermakna dan diastolik secara tidak bermakna pada penderita hipertensi. 


\section{DAFTAR PUSTAKA}

Almatsier, S. 2007. Penuntun Diet. Jakarta: PT. Gramedia Pustaka Utama

Androgue, HJ and Wesson, DE. 1994. Hypokalemia. Blackwell Scientific: 89-164

Badan Penelitian dan Pengembangan Kesehatan. Riset Kesehatan Dasar (RISKESDAS) Laporan Nasional 2007. Departemen Kesehatan Republik Indonesia; 2008

Badan Penelitian dan Pengembangan Kesehatan. Riset Kesehatan Dasar (RISKESDAS) 2013. Kementrian Kesehatan Republik Indonesia; 2013

Barbagallo, Mario et al. 2000. Effects of Aging on Serum Ionized and Cytosolic Free Calcium: Relation to Hypertension and Diabetes. hyper.ahajournals 34: 902-906

Benowitz, L. 2002. ObatAntihipertensi, dalam Katzung, B. G., 2002, Basic and Clinical Farmacology ed ke-3, Penerjemah: Bagian Farmakologi Fakultas Kedokteran Universitas Airlangga: Penerbit Salemba Medika

Blaustein MP, Zhang J, Chen L, Hamilton BP. 2006. How does salt retention raise blood pressure? Am J Physiol Regul Integr Comp Physiol 290: 514-23

Brown, E.M., Pollack M, Seidman C.E, et al. 1995. Calcium-ion-sensing cellsurface receptors. N Engl J Med 333: 234-40

Bustan, M.N. 2007. Epidemiologi Penyakit Tidak Menular. Jakarta: Rineka Cipta

Carl, Osborne et al. 1996. Lead Review Article: Evidence For The Relationship Of Calcium To Blood Pressure. Nutrition Review: 365

Chobanian AV, Bakris GL, Black HR, Cushman WC, Green LA, Izzo L, et al. 2003. The seventh report of Joint National Committe on Prevention, Detection, Evaluation, and Treatment of Hypertension. The JNC 7 report 289: 1560-72

Chris O. 2010. At a Glance: Sistem Ginjal (Terjemahan). Jakarta: Erlangga.

Ferrari P, Ferrandi M, Valentini G, Bianchi G. 2006. Rostafuroxin: an ouabain antagonist that corrects renal and vascular $\mathrm{Na}+-\mathrm{K}+$-ATPase alterations in ouabain and adducin-dependent hypertension. Am J Physiol Regul Integr Comp Physiol 290: 529-35.

Freadman D. 2002. Headache and hypertension: refuting the myth. J Neurol Neurosurg Psychiatry $72: 431$

Ganong, W. F. 2001. Fisiologi kedokteran. Adji Dharma, penerjemah Jakarta: Penerbit Buku Kedokteran EGC

Gharbawy et al. 2001. Arterial Pressure, Left Ventricular Mass and Aldosterone in Essential Hypertension. Hypertension 37: 845-50.

Guyton AC and Hall JE. 1997. Buku Ajar Fisiologi Kedokteran. Alih Bahasa: Irawati setiawan, LMA Ken Ariata Tengadi, Alex Santoso. Jakarta: EGC

Guyton AC , Hall JE. 2006. Textbook of Medical Physiology 11th edition. Phiadelphia: Elsevier Saunders

Heer M, Baisch F, Kropp J,Gerzer R. 2000. High dietary sodium chloride consumption may not 
induce body fluid retention in humans. Am J Physiol 278: 585-95

Hendrayani C. 2009. Hubungan Rasio Asupan Natrium:Kalium dengan Kejadian Hipertensi pada Wanita Usia 25-45 Tahun di Kompleks Perhubungan Surabaya. Skripsi. Semarang: Universitas Diponegoro/online

Horacio J. Adrogue, M.D., and Nicolaos E. Madias, M.D. 2007. Mechanisms Of Disease: Sodium and potassium in the pathogenesis of Hypertension. The new england journal of medicine 356: $1966-78$

Horne, Mima M. 2000. Keseimbangan Cairan, elektrolit, dan Asam Basa. Monica ester, penerjemah Jakarta: Buku Kedokteran EGC

Hugh E, De Wardener, Feng J. He, and Graham A. Macgregor. 2004. Plasma sodium and hypertension. Kidney International. Department of Clinical Chemistry, Imperial College, Charing Cross Hospital Campus, London, United Kingdom; and Blood Pressure Unit, St. George's Hospital Medical School, London, United Kingdom: 2454-66

Irawan, Anwari, M., 2007. Cairan Tubuh Elektrolit dan Mineral, Polton Sports Science and Performance Lab. http://www.pssplab.com/journal/01 .pdf. Diakses tanggal 13 April 2014

\section{Iwamoto T. 2006. Vascular $\mathrm{Na}+\mathrm{Ca} 2+$ exchanger: implications for}

Lawrence J. Appel et al. 2005. Dietary reference intakes for water potassium, sodium, chloride, and sulfate. Washington, DC: National Academies Press

Irza, S. 2009. Analisis Faktor Risiko Hipertensi pada masyarakat Nagari Bungo Tanjung Sumatera barat. Skripsi. Sumatra Utara: Fakultas Farmasi Universitas, online

Johnson AG,Nguyen TV,Davis D. 2001. Blood pressure is linked to salt intake and modulated by the angiotensinogen gene in normotensive and hypertensive elderly subjects. J Hypertens 19: $1053-60$

Kearney PM, Whelton M, Reynolds K, Muntner P, Whelton PK, He J. 2005. Global burden of hypertension: analysis of worldwide data. Lancet 365: 217- 23.

Kee Joyce dan Evelyn R. Hayes. 1996. Farmakologi Pendekatan Proses Keperawatan. dr. Peter Anugrah, penerjemah Jakarta : Buku Kedokteran EGC

Krum H, Martin J. 2007. Novel drug treatments for hypertension. Dalam: Hall JE, Lip GYH, Comprehensive hypertension. Philadelphia: Mosby 1049-60.

Kumar V, Abbas AK, Fausto N. 2005. Hypertensive Vascular Disease. Dalam: Robn and Cotran Pathologic Basis of Disease. Philadelpia: Elsevier Saunders 528- 29.

Lestari, D. 2010. Hubungan Asupan Kalium,Kalsium, Magnesium, dan Natrium,Indeks Massa Tubuh, serta Aktifitas Fisik dengan Kejadian Hipertensi pada Wanita Usia 30 - 40 Tahun. Skripsi. Semarang: Universitas Diponegoro/online

Masud, ibnu. 1996. Dasar-dasar fisiologi kardiovaskuler. Jakarta: EGC.

Meneton P, Jeunemaitre X, de Wardener HE, MacGregor GA. 2005. Links among dietary salt intake, renal salt handling, blood pressure, and cardiovascular diseases. Physiol Rev 85: 
679-715.

Newsholme, Eric A. and Tony R. 2010. Functional Biochemistry in Health and Disease. London: Editorial Assistant Mary Board St Hilda's College, Oxford A John Wiley \& Sons, Ltd.

NIH (National Institutes of Health). 2004. The Seventh Report of the Joint National Committee on Prevention, Detection, Evaluation, and Treatment of High Blood Pressure. U.S. Department Of Health And Human Services

Overlack A, Maus B, Ruppert M, Lennarz M, Kolloch R, Stumpe KO. 1995. Potassium citrate vs potassium chloride in essential hypertension: effect on haemodynamic, hormonal and metabolic parameters. Dtsch Med Wschr 120: 631-35

Palmer and Williams. 2007. Tekanan Darah Tinggi. Yasmine, Penerjemah Jakarta: Erlangga

Sarwono, Jonathan. 2006. Metode Penelitian Kuantitatif \& Kualitatif. Yogyakarta: Graha Ilmu.

Sobel BJ, et all. 1999. Hipertensi: Pedoman Klinis Diagnosis dan Terapi (Terjemahan). Jakarta: Hipokrates

Sudhakar K, Sujatha M, Babu SR, Padmavati P, Reddy PP. 2004. Serum calcium levels in patient with essential hypertension and their first degree relatives. Indian J Clin Biochem 19: 2123

Tanaka M, Schmidlin O, Yi S-L, Bollen AW, Morris RC. 1997. Genetically determined chloridesensitive hypertension and stroke. Proc Natl Acad Sci 94: 14748-52

Theodore A. Kotchen, MD. 2005. Contributions of Sodium and Chloride to NaCl-Induced Hypertension. Hypertension. Department of Medicine, Medical College of Wisconsin

Wannamethee G, Whincup PH, Shaper AG, Lever AF. 1994. Serum sodium concentration and risk of stroke in middle-aged males. JHypertens 12: 971-979

Wardener HE. 2001. The hypothalamus and hypertension. Physiol Rev 81: 1601-58

Whelton PK. 2003. Potassium and blood pressure. In: Izzo JL Jr, Black HR, eds. Hypertension primer. 3rd ed. Dallas: American Heart Association/Council on High Blood Pressure Research: 280-2.

Yeung, Albert. 2006. Hypertension: What is the Connection Between Hypertension, Headache and Migraine?. Canadian Hypertension Society 87.

Yingshui Y, Lianping H, Yuelong J, Yan C, Hui T, Xiuli S. 2013. The Relationship Among Serum Calcium Level, Blood Lipids, and Blood Pressure in Hypertensive and Normotensive Subjects who Come from a Normal University in East of China. Springer Science. New York: Business Media 